\title{
Application of the Point Stress Criterion to Assess the Bond Strength of a Single-Lap Joint
}

\author{
K. S. Sajikumar, ${ }^{\mathrm{a}}$ N. Asok Kumar, ${ }^{\mathrm{a}}$ and B. Nageswara Rao ${ }^{\mathrm{b}, 1}$ \\ ${ }^{a}$ Faculty of Mechanical Engineering, College of Engineering, Trivandrum, India \\ ${ }^{\mathrm{b}}$ Faculty of Mechanical Engineering, School of Civil and Mechanical Sciences, KL University, \\ Vaddeswaram, India \\ ${ }^{1}$ bnrao52@rediffmail.com
}

УДК 539.4

\section{Оценка адгезионной прочности соединения внахлестку по критерию точечных напряжений}

\author{
К. С. Саджикумар ${ }^{a}$, Н. Асок Кумар ${ }^{\text {, }}$ Б. Нагесвара Рао \\ а Факультет машиностроения, Инженерный колледж, Тривандрум, Индия \\ ${ }^{6}$ Факультет машиностроения, Высшая школа по гражданскому строительству и механике, КЛ \\ университет, Ваддесварам, Индия
}

Выполнен конечноэлементный расчет напряжений в зоне соединения внахлестку с использованием в адгезионном слое специальных 6-узловых изопараметрических конечных элементов. Результаты расчета хорошо согласуются с решениями, полученными в замкнутом виде Голандом и Рейсснером. Показано, что максимальные нормальные и касательные напряжения в адгезионном слое имеют место в ториах соединения, что обусловлено их сингулярностью. Оченена адгезионная прочность соединения внахлестку с помощью критерия прочности, известного как критерий точечных напряжений. Расчетные значения адгезионной прочности тесно коррелируют с известными экспериментальными данными.

Ключевые слова: адгезия, разрушающая нагрузка, метод конечных элементов, критерий точечных напряжений, соединение внахлестку.

Introduction. Adhesive bonding can offer better performance over the mechanical fastening and being used extensively in space, automobiles, construction industries, packaging industries etc. It has the ability to join dissimilar materials and to join efficiently thin sheet materials such as thin-walled composite structures [1]. Single-lap joint [2-7] and double-lap joint $[8,9]$ are simple in geometry and are widely used in characterizing adhesive behavior and structural connections. Failures in an adhesive joint are classified as adhesive failure and cohesive failure.

Adhesive failure occurs at the interface between the adhesive and adherend, whereas, the cohesive failure occurs either in the adhesive or in the adherend. Failure analysis of an adhesive joint requires reliable structural deformation and stresses in the joint for the applied loads. The mechanisms of adhesion are related to chemical and physical properties of the adhesive polymers. The structural deformation and stress states for the bonded joint configuration can be obtained by specifying material properties of the joint configuration, loads and appropriate boundary conditions. Since there is no unique failure criterion for the bonded joints, the designer has to select or establish a suitable criterion to estimate the joint strength [10-19]. The stress distribution for simple geometries can be obtained from a 
closed-form solution, which will be useful to validate the finite element models. Finite element analysis (FEA) is essential for analyzing complex geometries and structural materials. Da Silva et al. [20] have reviewed several analytical models. Stress analysis has been carried out for various joint configurations having different adherend and adhesive properties [21-28].

Standard finite elements are not well suited for modeling the adhesive layers which are extremely thin comparing to other dimensions of the bonded structure. Reasonably accurate results can be expected from the standard finite elements when the aspect ratio of the width to the height of the element is approximately unity. An element having a large aspect ratio becomes much stiffer in the transverse direction and much weaker in the axial direction. Backer and Hatt [29] have developed a linear element assuming thin adhesive layers which behave elastically as simple tension-compression springs and shear springs connecting the adherends. This assumption ignores the variation of the stresses in the thickness direction of the adhesive layer and influences equilibrium of the transverse normal stress and the longitudinal shear stress in the adhesive layer. Motivated by the work of Backer and Hatt [29], a special 6-node quadratic isoparametric element is developed [30] for modeling of the adhesive layers, which is compatible to the general 8-node quadratic isoparametric quadrilateral element [31] for modeling of the adherends. To examine the adequacy of the special 6-node isoparametric element for the adhesive layer, a single-lap metal-metal joint has been analyzed and compared with the results of the analytical solution of Goland and Reissner [21].

For predicting the static strength (failure load) of adhesives and adhesively bonded structures, the designers have adopted the strength of materials based models (e.g., average stress, maximum stress and maximum strain failure criterion) [23, 24, 32-34]; plastic yield criteria (e.g., von Mises and Tresca yield criterion, and Drucker-Prager plasticity model) $[35,36]$; void nucleation (cavitation) models [37]; and fracture-mechanics analysis [3843]. Motivated by the work of the above researchers, the bond strength of the single-lap joint is estimated through one of the stress fracture criteria known as the point stress criterion and compared with the results existing tests [44].

1. Test Results on Mild Steel Single-Lap Joints. Broughton et al. [44] have presented the failure load data on CR1 mild steel single-lap joints bonded with AV119 epoxy adhesive. Figure 1 shows a typical single-lap joint. The dimensions of the single-lap joint test specimens are: width $=25 \mathrm{~mm}$; length of adherends I and II $=100 \mathrm{~mm}$; thickness of adhesive, $t_{a}=0.25 \mathrm{~mm}$; thickness of adherends, $t_{1}=t_{2}=2.5 \mathrm{~mm}$, and the bond length, $a=12.5,25$, and $50 \mathrm{~mm}$. Table 1 gives the tensile and shear characteristics of CR1 mild steel and AV119 epoxy adhesive. Table 2 gives the failure loads of single-lap joints.

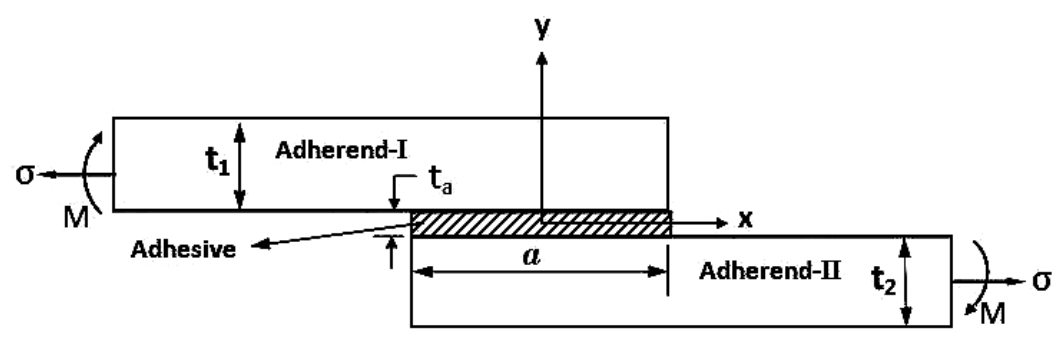

Fig. 1. Typical single-lap joint.

2. Finite Element Analysis. Muthurajan et al. [30] have adopted a numerical procedure for analyzing two-dimensional bonded joints, in which adherends are idealized by the 8-node quadratic isoparametric element [31] whereas the adhesive layer is modeled by a compatible 6-node special element. The 6-node quadratic special element for adhesive 
K. S. Sajikumar, N. Asok Kumar, and B. Nageswara Rao

$\mathrm{T}$ a $\mathrm{b} 1$ e 1

Tensile and Shear Characteristics of CR1 Mild Steel and AV119 Epoxy Adhesive

\begin{tabular}{|c|c|c|}
\hline \multirow[t]{2}{*}{ Characteristic } & CR1 mild steel & AV119 epoxy \\
\hline & \multicolumn{2}{|c|}{ Tension } \\
\hline Modulus (GPa) & $206 \pm 6$ & 3.05 \\
\hline Poisson's ratio & $0.38 \pm 0.02$ & 0.34 \\
\hline Ultimate strength (MPa) & $334 \pm 2$ & 71.3 \\
\hline Yield strength (MPa) & $206 \pm 1$ & - \\
\hline Ultimate strain (\%) & $4.23 \pm 0.50$ & - \\
\hline \multirow[t]{2}{*}{ Yieid strain (\%) } & $0.25 \pm 0.01$ & - \\
\hline & \multicolumn{2}{|c|}{ Shear } \\
\hline Shear modulus (GPa) & $74 \pm 4$ & 1.1 \\
\hline Strength (MPa) & - & 41.0 \\
\hline
\end{tabular}

$\mathrm{T}$ a b 1 e 2

Failure Loads for CR1 Mild Steel/AV119 Single-Lap Joints

\begin{tabular}{|c|c|}
\hline Bond length $a(\mathrm{~mm})$ & Failure load $(\mathrm{N})$ \\
\hline 12.5 & $8850 \pm 250$ \\
\hline 25.0 & $10700 \pm 950$ \\
\hline 50.0 & $15825 \pm 1575$ \\
\hline
\end{tabular}

Note. Width $=25 \mathrm{~mm}$, thickness of adhesive $t_{a}=0.25 \mathrm{~mm}$, and thickness of adherends $t_{1}=t_{2}=$ $=2.5 \mathrm{~mm}$.

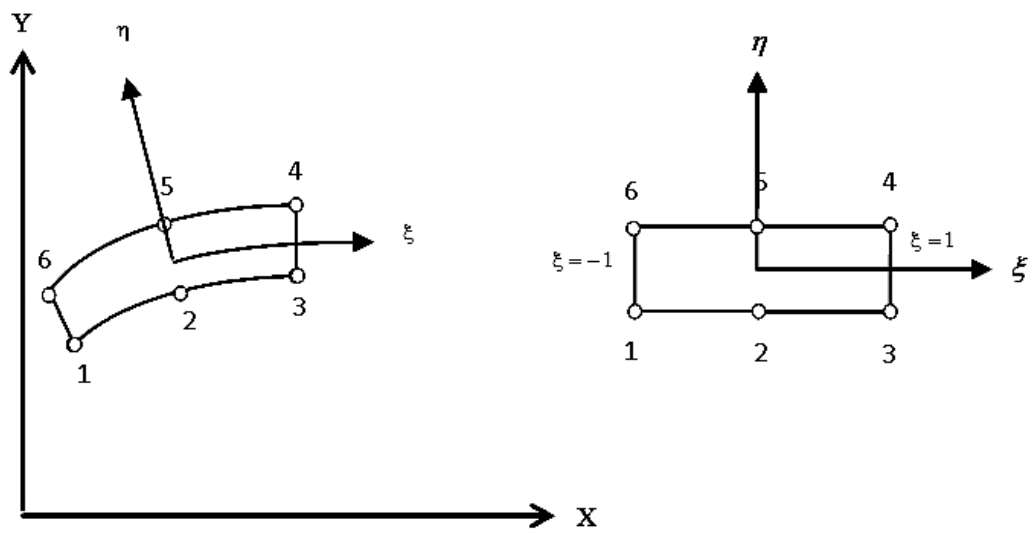

Fig. 2. Special 6-node quadratic element for adhesive layer.

layer (Fig. 2) is found to be more appropriate when compared to the linear element of Barker and Hatt [29]. Since the adhesive layer is relatively thin, the special element assumes identical coordinates for the top and bottom nodes of the adhesive element. As in [29], the adhesive element neglects the longitudinal direct stress as well as the other two stresses across the adhesive thickness. 
The adhesive element stiffness matrix is [30]:

$$
[K]^{e}=t_{a} \int_{-1}^{1}[R]^{T}[B]^{T}[D]_{a}[B][R]\left\{\left(\frac{\partial x}{\partial \xi}\right)^{2}+\left(\frac{\partial y}{\partial \xi}\right)^{2}\right\}^{1 / 2} d \xi
$$

Here $[B]=\left\{\begin{array}{llllll}-B_{1} & -B_{2} & -B_{3} & B_{1} & B_{2} & B_{3}\end{array}\right\}$ is the strain-shape function matrix, $B_{i}^{T}=$ $=\left[\begin{array}{ccc}0 & 0 & N_{i} \\ 0 & -N_{i} & 0\end{array}\right],[D]_{a}=\left[\begin{array}{ccc}0 & 0 & 0 \\ 0 & E_{a} & 0 \\ 0 & 0 & G_{a}\end{array}\right]$ is the material matrix for the adhesive element, $E_{a}$ and $G_{a}$ are the Young modulus and shear modulus of the adhesive layer having thickness $t_{a}$. The transformation matrix $[R]$ is the diagonal matrix having six identical elements and each element is a $2 \times 2$ matrix $S=\left[\begin{array}{cc}\cos \theta & \sin \theta \\ -\sin \theta & \cos \theta\end{array}\right]$, in which $\theta=$ $=\tan ^{-1}\left\{\left(\frac{\partial y}{\partial \xi}\right)\left(\frac{\partial x}{\partial \xi}\right)^{-1}\right\}$.

The local normal strain $\varepsilon$ and shear strain $\gamma$ are

$$
\begin{gathered}
\varepsilon=\frac{v^{\text {top }}-v^{\text {bottom }}}{t_{a}}, \\
\gamma=\frac{u^{\text {top }}-u^{\text {bottom }}}{t_{a}} .
\end{gathered}
$$

The local displacements $(u, v)$ of the top and bottom adhesive layer are

$$
\left\{\begin{array}{l}
u \\
v
\end{array}\right\}^{\text {top }}=\sum_{i=1}^{3} N_{i}(\xi)\left\{\begin{array}{c}
u_{i+3} \\
v_{i+3}
\end{array}\right\}, \quad\left\{\begin{array}{l}
u \\
v
\end{array}\right\}^{\text {bottom }}=\sum_{i=1}^{3} N_{i}(\xi)\left\{\begin{array}{c}
u_{i} \\
v_{i}
\end{array}\right\}
$$

The top and bottom nodes of the adhesive element having identical coordinates is represented by

$$
\left\{\begin{array}{l}
x \\
y
\end{array}\right\}=\sum_{i=1}^{3} N_{i}(\xi)\left\{\begin{array}{c}
x_{i} \\
y_{i}
\end{array}\right\}
$$

The shape functions $N_{i}(i=1,2,3)$ in Eqs. (4) and (5) for the adhesive element are

$$
N_{1}(\xi)=-\frac{1}{2} \xi(1-\xi), \quad N_{2}(\xi)=1-\xi^{2}, \quad N_{3}(\xi)=\frac{1}{2} \xi(1+\xi) .
$$

The special six-node quadrilateral adhesive element is compatible to the standard eight-node isoparametric quadrilateral 2D plane element. Standard finite element procedure is adopted to obtain the overall structural deformation, strains and stresses for the specified (applied) load.

Figure 3 shows the finite element model for the $12.5 \mathrm{~mm}$ bond length. Following [30], finite element analysis has been carried out by applying the tensile force $8850 \mathrm{~N}$ parallel to the adherend and also external moments which satisfy the moment-equilibrium condition. 


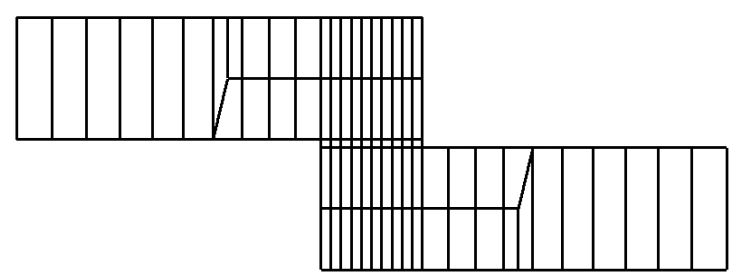

Fig. 3. Finite element model [30].

Characteristics of material are specified from Table 1. Displacement along $x$-direction (loading direction) is suppressed at the left side edge of the adherend (adherend-I). Also displacement along $y$-direction is suppressed at the middle node of the left side edge of the adherend (adherend I). An edge load $(P)$ equivalent to 141.6 MPa tensile stress plus the external moment is applied at the right side edge of the adherend (adherend II). The shear stress $\left(\tau_{x y}\right)$ and normal or peel stress $\left(\sigma_{y}\right)$ distributions in the adhesive layer of steel-steel single-lap joint are shown in Figs. 4 and 5.

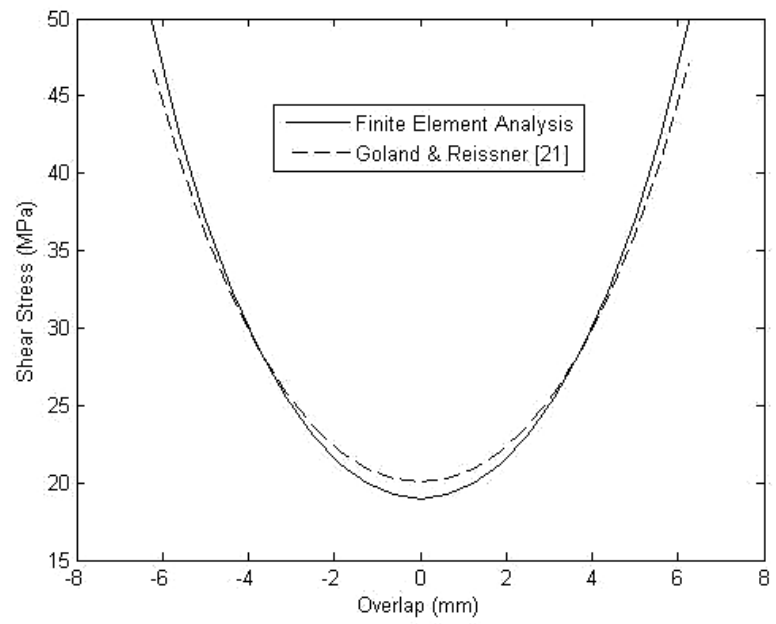

Fig. 4. Comparison of shear stress distribution in the adhesive layer of a single lap joint.

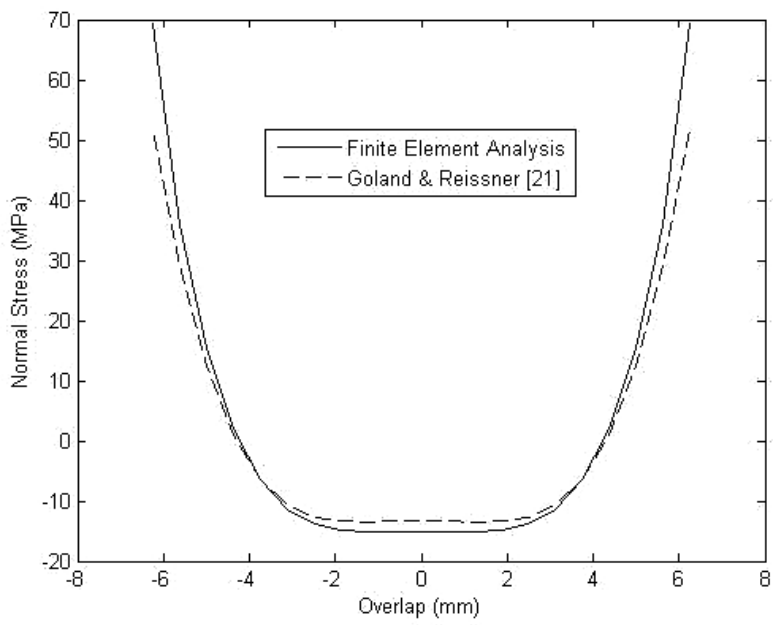

Fig. 5. Comparison of normal stress distribution in the adhesive layer of a single lap joint. 
The finite element analysis results are found to be in good agreement with the closed-form solution of Goland and Reissner [21]:

$$
\begin{gathered}
\tau_{x y}=\frac{P}{4 a} \psi_{1}\left(\frac{\gamma_{1} x}{t}\right), \\
\sigma_{y}=\frac{P}{t} \psi_{2}\left(\frac{2 \gamma_{2} x}{a}\right) .
\end{gathered}
$$

Here

$$
\begin{gathered}
\psi_{1}(\xi)=A_{1} \cosh \xi+B_{1}, \quad \psi_{2}(\xi)=A_{2} \cosh \xi \cos \xi+B_{2} \sinh \xi \sin \xi \\
A_{1}=\frac{\gamma_{1} a}{2 t}\left(1+3 \delta_{1}\right)\left\{\sinh \left(\frac{\gamma_{1} a}{2 t}\right)\right\}^{-1}, \quad B_{1}=3\left(1-\delta_{1}\right), \quad A_{2}=\left(\delta_{3}-\delta_{4}\right) \delta_{7}, \\
B_{2}=\left(\delta_{5}-\delta_{6}\right) \delta_{7}, \quad \gamma_{1}=2 \sqrt{\frac{2 G_{a} t}{E t_{a}}}, \quad \gamma_{2}=\frac{a}{2 t} \sqrt[4]{\frac{6 E_{a} t}{E t_{a}}}, \quad \gamma_{3}=\frac{a}{2 t} \sqrt{\frac{3}{2}\left(1-v^{2}\right) \frac{P}{E t}} \\
\delta_{1}=\left\{1+2 \sqrt{2} \tanh \gamma_{3}\right\}^{-1}, \quad \delta_{2}=\frac{1}{2}\left(\sinh \gamma_{2}+\sin \gamma_{2}\right), \\
\delta_{3}=\frac{\gamma_{2}}{2}\left(\sinh \gamma_{2} \cos \gamma_{2}-\cosh \gamma_{2} \sin \gamma_{2}\right), \quad \delta_{4}=\sqrt{2} \gamma_{3} \cosh \gamma_{2} \cos \gamma_{2}, \\
\delta_{5}=\frac{\gamma_{2}}{2}\left(\cosh \gamma_{2} \sin \gamma_{2}+\sinh h \gamma_{2} \cos \gamma_{2}\right), \quad \delta_{6}=\sqrt{2} \gamma_{3} \sinh \gamma_{2} \sin \gamma_{2}, \\
\delta_{7}=\left(\frac{2 t}{a}\right)^{2} \frac{\delta_{1}}{\delta_{2}} \gamma_{2} .
\end{gathered}
$$

The Young moduli of the adherend and the adhesive layer are designated by $E$ and $E_{a}$, respectively, whereas the shear modulus of the adhesive layer is represented by $G_{a}$, $v$ is Poisson's ratio of adherends, $a$ is the overlap length, $P$ is the load for unit width, $t$ is the thickness of the adherend, and $t_{a}$ is the thickness of the adhesive layer.

3. Failure Load Estimation. Maximum normal and shear stresses are found in the adhesive layer at the ends of the overlap. The distribution is symmetric in either side from the center of the joint. It is interesting to note that the average of normal stress in the adhesive layer is found to be zero, whereas the average shear stress in the adhesive layer is found to be equivalent to the ratio of the applied load and the adhesive area. Since the stress fields near the bonding edges show singular behavior or stress concentration, it is essential to understand the failure behavior of bonded joints and the appropriate failure criterion for life predictions. One of the stress factor criteria of the Whitney and Nuismer [45] known as the point stress criterion (PSC) states that fracture occurs when the stress ahead of the discontinuity at the characteristic distance is equal to the strength of the material.

For the present problem, failure loads of single-lap joints are specified in Eq. (7) and obtained the shear stress distribution over the overlap length of the adhesive layer. As expected, the shear stress at the ends of the overlap is found to be higher than the shear strength of the adhesive. Following the point stress criterion, the characteristic length $\left(a_{c b}\right)$ is found in the overlap region at which the shear stress in the adhesive layer for the failure 
load is equal to the shear strength of the adhesive. From the test results of Table 2, an empirical relation is developed for the characteristic length in terms of the overlap length of the single-lap joint as

$$
a_{c b}=0.1786 a^{0.5025} \text {. }
$$

In order to obtain the shear strength of single-lap joint, the shear stress distribution is obtained from Eq. (7) specifying unit load and finding the stress value at the characteristic distance from the bonding edge. This stress value is multiplied with the shear strength by the shear strength of the adhesive. The failure load is obtained by multiplying the resulting shear strength value with the overlap area of the bond. Tables 3 and 4 give the comparison of failure load for CR1 mild steel/AV119 single-lap joints. The failure load estimates based on point stress criterion is found to be in good agreement with test results [44].

$\mathrm{T}$ a b 1 e 3

Prediction of Failure Loads (N) for CR1 Mild Steel/AV119 Single-Lap Joints

\begin{tabular}{|c|c|c|c|}
\hline \multirow{2}{*}{$\begin{array}{c}\text { Failure } \\
\text { criterion [44] }\end{array}$} & \multicolumn{3}{|c|}{ Bond length, $a(\mathrm{~mm})$} \\
\hline & 12.5 & 25 & 50 \\
\hline & \multicolumn{3}{|c|}{ Maximum shear stress criterion } \\
\hline FEA (von Mises) & 6285 & 7655 & 10482 \\
\hline FEA (linear Drucker-Prager) & 6110 & 7540 & 12287 \\
\hline \multirow[t]{2}{*}{ Analytical solution } & 10545 & 10808 & 11674 \\
\hline & \multicolumn{3}{|c|}{ Maximum tensile stress criterion } \\
\hline FEA (von Mises) & 6295 & 7715 & 10656 \\
\hline FEA (linear Drucker-Prager) & 6105 & 7517 & 12175 \\
\hline \multirow[t]{2}{*}{ Analytical solution } & 15014 & 16014 & 18068 \\
\hline & \multicolumn{3}{|c|}{ Hill's failure criterion } \\
\hline FEA (von Mises) & 4076 & 4900 & 6683 \\
\hline FEA (linear Drucker-Prager) & 4426 & 5321 & 7219 \\
\hline \multirow[t]{2}{*}{ Analytical solution } & 8627 & 8968 & 9818 \\
\hline & \multicolumn{3}{|c|}{ Maximum shear strain criterion } \\
\hline FEA (von Mises) & 8711 & 10168 & 13512 \\
\hline \multirow[t]{2}{*}{ FEA (linear Drucker-Prager) } & 7985 & 10594 & 13930 \\
\hline & \multicolumn{3}{|c|}{ Maximum tensile strain criterion } \\
\hline FEA (von Mises) & 7395 & 9526 & 12833 \\
\hline \multirow[t]{2}{*}{ FEA (linear Drucker-Prager) } & 7280 & 9282 & 12727 \\
\hline & \multicolumn{3}{|c|}{ Maximum principal strain criterion } \\
\hline FEA (von Mises) & 5878 & 7115 & 9735 \\
\hline FEA (linear Drucker-Prager) & 5722 & 6918 & 9401 \\
\hline Experimental & $8850 \pm 250$ & $10700 \pm 950$ & $15825 \pm 1575$ \\
\hline Present analysis & 8850 & 11625 & 15800 \\
\hline
\end{tabular}

Note. Width $=25 \mathrm{~mm}$, length of adherends $=100 \mathrm{~mm}$, thickness of adhesive $=0.25 \mathrm{~mm}$, and thickness of adherends $=2.5 \mathrm{~mm}$. 
Application of the Point Stress Criterion ...

$\mathrm{T}$ a b 1 e 4

Prediction of Failure Loads (N) for CR1 Mild Steel/AV119 Single-Lap Joints

\begin{tabular}{|c|c|c|c|c|}
\hline \multirow{2}{*}{$\begin{array}{l}\text { Specimen width } \\
(\mathrm{mm})\end{array}$} & \multirow{2}{*}{$\begin{array}{l}\text { Bond length } \\
(\mathrm{mm})\end{array}$} & \multicolumn{3}{|c|}{ Failure load $(\mathrm{N})$} \\
\hline & & FEA [44] & Experimental [44] & Present analysis \\
\hline 15 & 12.5 & 4940 & $4610 \pm 146$ & 5310 \\
\hline 50 & 50 & 26430 & $31940 \pm 482$ & 31600 \\
\hline 50 & 100 & 29622 & $36737 \pm 450$ & 45450 \\
\hline
\end{tabular}

Note. Length of adherends $=100 \mathrm{~mm}$, thickness of adhesive $=0.25 \mathrm{~mm}$, and thickness of adherends $=2.5 \mathrm{~mm}$.

Conclusions. This paper adopts the point stress criterion to estimate the bond strength of a single-lap metal-metal joint specimen. A special 6-node quadratic isoparametric element for idealizing the adhesive layer and a general 8-node quadrilateral isoparametric element for idealizing the adherends as in [30] are considered while analyzing the single-lap joint. The finite element analysis results are found to be in good agreement with the analytical solution of Goland and Reissner [21]. Finite element modeling and analysis will be useful to obtain the solution for the joint problems of complex shaped adherends (for optimum joint efficiency) and different adherend materials. Failure load estimates of the single-lap joints following the present point stress criterion are found to be in good agreement with test results.

\section{Резгме}

Проведено скінченноелементний розрахунок напружень у зоні з'єднання внапуск із використанням у адгезійному шарі спеціальних 6-вузлових ізопараметричних скінченних елементів. Результати розрахунку добре узгоджуються з розв'язками, отриманими у замкненому вигляді Голандом і Рейсснером. Показано, що максимальні нормальні і дотичні напруження в адгезійному шарі мають місце в торцях з'єднання, що зумовлено їх сингулярністю. Оцінено адгезійну міцність з'єднання внапуск за допомогою критерію міцності, відомого як критерій точкового напруження. Розрахункові значення адгезійної міцності тісно корелюють із відомими експериментальними даними.

1. L. Tong and G. P. Steven, Analysis and Design of Structural Bonded Joints, Kluwer Academic Publishers, Boston (1999).

2. W. C. Carpenter, "Goland and Reissner were correct," J. Strain Anal., 24, No. 3, 185-187 (1989).

3. G. Li and P. Lee-Sullivan, "Finite element and experimental studies on single-lap balanced joints in tension," Int. J. Adhes. Adhesiv., 21, No. 3, 211-220 (2001).

4. M. Y. Tsai and J. Morton, “An experimental investigation of nonlinear deformations in single-lap joints," Mech. Mater., 20, 183-194 (1995).

5. Q. Luo and L. Tong, "Analytical solutions for nonlinear analysis of composite single-lap adhesive joints," Int. J. Adhes. Adhesiv., 29, No. 2, 144-154 (2009).

6. L. D. R. Grant, R. D. Adams, and L. F. M. da Silva, "Experimental and numerical analysis of single-lap joints for the automotive industry," Int. J. Adhes. Adhesiv., 29, No. 4, 405-413 (2009).

7. T. R. Guess, R. E. Allred, and F. P. Gerstle, Jr., "Comparison of lap shear test specimens," J. Test. Eval., 5, No. 3, 84-93 (1977). 
8. P. Chalkley and F. Rose, "Stress analysis of double-strap bonded joints using a variational method," Int. J. Adhes. Adhesiv., 21, No. 3, 241-247 (2001).

9. H. Osnes and D. McGeorge, "Experimental and analytical strength analysis of double-lap joints for marine applications," Composites: Part B, 40, 29-40 (2009).

10. A. Gacoin, P. Lestriez, J. Assih, et al., "Comparison between experimental and numerical study of the adhesively bonded scarf joint and double scarf joint: Influence of internal singularity created by geometry of the double scarf joint on the damage evolution," Int. J. Adhes. Adhesiv., 29, No. 5, 572-579 (2009).

11. A. F. Avila and P. de O. Bueno, "An experimental and numerical study on adhesive joints for composites," Compos. Struct., 64, 531-537 (2004).

12. G. C. McGrath, "The performance of adhesive joints-a UK initiative," Int. J. Adhes. Adhesiv., 17, No. 4, 339-343 (1997).

13. Naveen Rastogi, B. P. Deepak and S. R. Soni, "Stress analysis codes for bonded joints in composite structures," AIAA-97-1341 (1997), pp. 2772-2782.

14. A. Öchsner and J. Gegner, "Application of the finite element method in the tensileshear test of adhesive technology," Int. J. Adhes. Adhesiv., 21, No. 4, 349-353 (2001).

15. L. F. M. da Silva and R. D. Adams, "Techniques to reduce the peel stresses in adhesive joints with composites," Int. J. Adhes. Adhesiv., 27, No. 3, 227-235 (2007).

16. G. P. Zou, K. Shahin, and F. Taheri, "An analytical solution for the analysis of symmetric composite adhesively bonded joints," Compos. Struct., 65, 499-510 (2004).

17. D. P. Romilly and R. J. Clark, "Elastic analysis of hybrid bonded joints and bonded composite repairs," Compos. Struct., 82, 563-576 (2008).

18. A. A. Taib, R. Boukhili, S. Achiou, and H. Boukehili, "Bonded joints with composite adherends. Part II: Finite element analysis of joggle lap joints," Int. J. Adhes. Adhesiv., 26, No. 4, 237-248 (2006).

19. D. Castagnetti and E. Dragoni, "Standard finite element techniques for efficient stress analysis of adhesive joints," Int. J. Adhes. Adhesiv., 29, No. 2, 125-135 (2009).

20. L. F. M. da Silva, P. J. C. das Neves, R. D. Adams, and J. K. Spelt, "Analytical models of adhesively bonded joints - Part I: Literature survey," Int. J. Adhes. Adhesiv., 29, No. 3, 319-330 (2009).

21. M. Goland and E. Reissner, "The stresses in cemented joints," J. Appl. Mech., 11, A17-A27 (1944).

22. F. Erdogan and M. Ratwani, "Stress distribution in bonded joints," J. Compos. Mater., 5, 378-393 (1971).

23. L. J. Hart-Smith, Adhesive-Bonded Scarf and Stepped-Lap Joints, NASA CR-112237 (January 1973).

24. L. J. Hart-Smith, Analysis and design of advanced composite bonded joints, NASA CR-2218 (August 1974).

25. D. J. Chang and R. Muki, "Stress distribution in a lap joint under tension-shear," Int. J. Solids Struct., 10, 503-517 (1974).

26. M. N. Reddy and P. K. Sinha, "Stresses in adhesive-bonded joints for composites," Fibre Sci. Technol., 8, 33-47 (1975).

27. T. S. Ramamurthy and A. K. Rao, "Shaping of adherends in bonded joints," Int. J. Mech. Sci., 20, 721-727 (1978).

28. U. Yuceoglu and D. P. Updike, "Stress analysis of bonded plates and joints," J. Eng. Mech., 106, 37-56 (1980). 
29. R. M. Barker and F. Hatt, "Analysis of bonded joints in vehicular structures," AIAA J., 11, 1650-1654 (1973).

30. K. G. Muthurajan, K. Sankaranarayana Samy, S. B. Tiwari, and B. Nageswara Rao, "Finite element modeling of adhesively bonded joints," Trends Appl. Sci. Res., 1, No. 1, 25-40 (2006).

31. O. C. Zienkiewicz, The Finite Element Method in Engineering Sciences, McGraw Hill, London (1971).

32. J. A. Harris and R. D. Adams, "Strength prediction of bonded single lap joints by non-linear finite element methods," Int. J. Adhes. Adhesiv., 4, No. 2, 65-78 (1984).

33. R. D. Adams, "The mechanics of bonded joints," in: Structural Adhesives in Engineering, ImechE Conference Publications, Suffolk (1986), pp. 17-24.

34. P. K. Mallick (Ed.), Composites Engineering Handbook, Marcel Dekker, Inc. (1997).

35. C. H. Wang and P. Chalkley, "Plastic yielding of a film adhesive under multiaxial stresses," Int. J. Adhes. Adhesiv., 20, No. 2, 155-164 (2000).

36. G. D. Dean and L. Crocker, Comparison of the Measured and Predicted Deformation of an Adhesively Bonded Lap-Joint Specimen, NPL Report CMMT (A) 293 (2000).

37. A. L. Gurson, "Continuum theory of ductile rupture by void nucleation and growth: Part I - Yield criteria and flow rules for porous ductile media," J. Eng. Mater. Technol., 99, No. 1, 2-15 (1977).

38. H. L. Groth, "A method to predict fracture in an adhesively bonded joint," Int. J. Adhes. Adhesiv., 5, No. 1, 19-22 (1985).

39. H. L. Groth, "Stress singularities and fracture at interface corners in bonded joints," Int. J. Adhes. Adhesiv., 8, No. 2, 107-113 (1988).

40. G. Fernlund and J. K. Spelt, "Failure load prediction of structural adhesive: Part 1: Analytical method," Int. J. Adhes. Adhesiv., 11, No. 4, 213-220 (1991).

41. G. Fernlund and J. K. Spelt, "Failure load prediction of structural adhesive: Part 2: Experimental results," Int. J. Adhes. Adhesiv., 11, No. 4, 221-227 (1991).

42. G. Fernlund, M. Papini, D. McCammond, and J. K. Spelt, "Fracture load predictions for adhesive joints," Compos. Sci. Technol., 51, 587-600 (1994).

43. A. J. Curley, H. Hadavinia, A. J. Kinloch, and A. C. Taylor, "Predicting the service-life of adhesively-bonded joints," Int. J. Fract., 103, 41-69 (2000).

44. W. R. Broughton, L. E. Crocker, and J. M. Urquhart, Strength of Adhesive Joints: a Parametric Study, NPL Report MATC (A) 27 (2001).

45. J. Whitney and R. Nuismer, "Stress fracture criteria for laminated composites containing stress concentrations," J. Compos. Mater., 8, 253-265 (1974). 